
https://orcid.org/ 0000-0002-9028-5817 ResearcherID: W-4750-2018 G. Krusir, Dr of Technical Science, Professor ${ }^{1}$, E-mail: krussir.65@ gmail.com https://orcid.org/ 0000-0001-6464-5754

ResearcherID: F-1312-2016

V. Zakharchuk, PhD of Technical Sciences, Associate Professor ${ }^{2}$, ResearcherID: B-2999-2015

${ }^{1}$ Odessa National Academy of Food Technologies, str. Kanatnaya, 112, Odessa, 65039, Ukraine Tel. +380487124013

${ }^{2}$ Odessa National Economic University, str. Preobrazhenskaya 8, Odessa, 65000, Ukraine

\title{
INVESTIGATION OF ENZYMATIC HYDROLYSIS OF FATTY WASTE PROCESSING OF SUNFLOWER SEEDS BY IMMOBILIZED LIPASE
}

\begin{abstract}
Ukraine has a developed agricultural sector, in particular crop production, which is a source of large quantities of production residues and waste. One of the most promising areas for solving environmental problems in the production of grain products is the processing of industrial waste by enzymes and the use of processing products in other industries. The current needs of sustainable environmental practices have increased the use of enzymatic technologies in production processes. Lipases be used in the processing of waste from oil and fat enterprises, namely, waste from the stage of demetallization of hydrogenated fat from vegetable oils by enzymatic hydrolysis.The work is devoted to the study of conditions of enzyme Rhizopus japonicus lipase immobilization and its physical and chemical characteristics. Factors for obtaining immobilized biocatalysts, methods and conditions for determining the activity and stability of immobilized enzymes are highlighted. Lipolytic activity of the enzyme immobilized under these conditions remains more than $30 \%$ compared to native, which is a high indicator of activity retention.

It has been shown that immobilization promotes the expansion of the $\mathrm{pH}$ - and thermo-optimum of the lipase. It was determined that for the Rhizopus japonicus immobilized lipase, the pH optimum increased with a shift from 7.0 to 6.5 , and there was an increase in $\mathrm{pH}$ stability during prolonged incubation of the immobilized enzyme for alkaline and acidic pH values. It has been established that lipase immobilization leads to expansion of the thermo-optimum, as well as stabilization of the enzyme during prolonged incubation at $40^{\circ} \mathrm{C}$ and at higher temperatures $\left(+60-80^{\circ} \mathrm{C}\right)$, which are possible when drying the final product.

The high activity and stability of the immobilized lipase make it possible to recommend it for biotechnological processing of oil-fat waste.

Keywords: environmental biotechnology, waste, straw, oil and fat industry, immobilization, enzyme, lipase, Rhizopus japonicus, adsorption.
\end{abstract}

\section{Introduction}

The oil and fat industry of Ukraine today has a dynamic of sustainable development and remains an integral part of the global market for oilseeds and their processed products. The world market for sunflower oil is 10 million tons, and Ukraine occupies $60 \%$ of this market. The main type of oils in the Ukrainian market is sunflower $-70 \%$ of the total market turnover. At various stages of the processing of vegetable raw materials waste and by-products are formed, which contain a significant content of fatty acids and related substances. The technology of purification of vegetable oils, namely the process of hydrogenation, is accompanied by the formation of such wastes as spent clay from the stage of additional bleaching and spent catalyst. Spent clay waste is a hazard class IV waste, a spent hazard class III catalyst. Depending on the technology, about 80 tonnes of waste accumulates annually at an oil refinery with a capacity of 100 tonnes / day.

One of the most important tasks of the food industry is the development of integrated processing of raw materials and waste, as well as improving the efficiency of this processing. In the modern world, thanks to the rapid development of biotechnology, a scientific discovery in the field of enzymology, enzyme preparations have become widely used in many industries. Lipases can be used in almost all biotechnological processes to produce valuable products. In our case, this is the processing of waste from oil and fat enterprises, namely, waste from the stage of demetallization of hydrogenated fat from vegetable oils (process of hydrogenation) by enzymatic hydrolysis [1].

\section{Literary review}

Industrial processes increase the tendency to destabilize enzymes, reducing their industrial life. In this regard, an urgent problem is to increase the stability and effectiveness of lipase by immobilizing enzyme preparations, increasing the number of enzyme molecules per unit area, increasing the efficiency of enzymatic hydrolysis. For the effective implementation of the enzymatic transformation process, it is necessary to know under what conditions the maximum activity is manifested, what factors and how affect the enzyme [2,3].

Immobilization is used to make the use of enzymes more effective in biotechnological processes. 
Compared with native, immobilized enzyme preparations are characterized by a number of advantages, such as the expansion of $\mathrm{pH}$ and thermo-optimums of action, increase of $\mathrm{pH}$ and thermal stability, prolongation of the action of immobilized enzymes, the matrix in the functioning of immobilized preparations in real conditions, protects the enzyme from aggressive action $[1,2]$.

The most effective method of stabilizing enzymes is their immobilization on carriers of different nature. As a matrix for immobilization of lipases cation exchange and chelate resins, hydrophobic carriers, anion exchangers are used In addition, a method for producing immobilized lipase particles is provided, comprising the steps of producing an emulsion, where the aqueous phase that dissolves the lipase and the substance acting as a lipase carrier are dispersed in a hydrophobic phase, followed by removal of water from the emulsion to convert its aqueous phase to solid particles coated with lipase [4].

Methods for immobilizing lipases include adsorption on insoluble carriers; incorporation of the gel into the pores; spatial separation of the enzyme from the rest of the volume of the reaction mixture by a membrane; inclusion in a two-phase reaction medium where the enzyme is soluble and can only be contained in one of the phases and the like. Analysis of the literature shows that adsorption methods are the most effective. This is due to the ease of the binding process, the low cost of the carrier and the absence of toxic substances. Adsorption immobilization provides a large surface area, which is important for lipolytic enzymes that carry out catalysis on the phase interface. Various media are used to immobilize lipolytic enzymes by adsorption: silicon dioxide, cellulose, zeolites, polyethylene, polystyrene, activated carbon, diatomaceous earth, synthetic resins, porous nylon, hydrophobic zeolite, polypropylene, aluminium oxide, amberlite and such like [2,5].

The most effective matrices for lipase immobilization are activated carbon, clays and biopolymer matrices. Various inorganic clays, namely, diatomaceous earth, ascanite, bergmeal, activated carbon, are widely used for the preparation of immobilized forms of enzymes and other biologically active substances used in industry. This is due to their characteristics such as high adsorption properties, developed surface in combination with sufficient permeability for substrates, and the presence of different functional groups [6].

Activated carbon is bacterial, mechanical, chemical resistant, has a developed surface, does not swell in liquids, and the surface of activated carbon can be modified $[7,8,9]$. The method has proven effective in applying lipase in continuous reactors to mesoporous activated carbon. Mesopores create a space for the enzyme that prevents the desorption of the lipase from the surface of the activated carbon and at the same time preserves its activity. Analysis of the studies on the study of biocatalysts based on activated carbon and lipase shows that the activity of the created samples is higher than for the native enzyme $[10,11]$.

Food clays of inorganic origin were selected as matrices for enzyme immobilization and others are polymer matrices that are most widely used as enzyme carriers and are used in the oil and fat industry. The pres- ence of different functional groups in them, the developed surface causes their high sorption capacity in relation to inorganic and other polar molecules.

After immobilization, the enzyme undergoes changes in physical and chemical properties, depending on the choice of method of immobilization. The physical and chemical characterization of the immobilized enzyme is its stability - the ability to retain catalytic activity under certain conditions. The stability of the structure of the enzyme itself, as well as the nature of its interaction with the surrounding particles, is determined. The stability of the enzyme is also inferred from its residual activity after incubation for a certain time, at a certain temperature and $\mathrm{pH}$ of the medium [13].

Researchers pay close attention to the effects of $\mathrm{pH}$ and temperature on lipase stability. Moreover, these two factors are important applications and must be taken into account.

In work [1] showed the effectiveness of the use of Rhizopus japonicus lipase in the hydrolysis of hydrogenated fat and determined the conditions for productive waste hydrolysis. Lipase weight ratio: substrate 1:50, ambient temperature $+40^{\circ} \mathrm{C}, \mathrm{pH}$ of the reaction mixture 7.0. The previously reported experimental data indicate a low $\mathrm{pH}$ - and thermal stability of the enzyme, indicating the need for its stabilization.

\section{Formulation of the problem}

The purpose of the work is to develop conditions for the immobilization of Rhizopus japonicus lipase and to study the physical and chemical properties of the immobilized Rhizopus japonicus lipase.

The objective of the work is to determine the optimal weight ratio of the carrier: enzyme; to investigate the dependence of the activity of immobilized lipase on the hydromodule, on temperature, on the duration of immobilization; dependence of the lipolytic activity of immobilized lipase on particle size, $\mathrm{pH}$ optimum, $\mathrm{pH}$ stability and thermal optimum, thermal stability of immobilized lipase.

\section{Materials and methods}

The objects of study were hydrogenation waste of vegetable oils and fats, namely that of the bleaching process. In order to eliminate the influence on the lipase of the mineral substances contained in the waste, $40 \%$ of the brine emulsion was used as a substrate, which is the main component of the waste of its production. Rhizopus japonicus lipase produced by Enzim enterprise (Ladyzhyn, Vinnytsia region, Ukraine) was considered as a part of waste, which shows the highest activity in relation to hydrogenated fat, substantiates its use for hydrogenated fat hydrolysis. To study the adsorption processes of Rhizopus japonicus lipase, we used carriers Kieselguhr (Tripel Group LLC, Kirovograd Mechanical Plant CJSC), Ascanite (Askangel Alliance Georgia LLC), activated carbon (First Gas Industrial Company LLC), bergmeal (Bergmeal LLC Group", CJSC "Kirovograd Mechanical Plant"), agar-agar (LLC "Khimsnabzhenie"), carrageenan (LLC "Khimsnabzhenie"), chitosan (Xi'an Sonwu Biotech Co., Ltd.).

The lipolytic activity was determined by the titrometric method of Ota and Yamada [15], which is 
based on the calculation of the amount of fatty acids formed during the hydrolysis of the substrate. As a substrate, $40 \%$ emulsion of hydrogenated fat was used, which was stabilized with polyvinyl alcohol. An activity unit was taken up by the amount of enzyme that releases 1 micromole of acid from $40 \%$ suspension of hydrogenated fat at $+37^{\circ} \mathrm{C}$ for 1 hour. In a test tube containing 8$15 \mathrm{mg}$ of the sample, $1 \mathrm{~cm}^{3}$ of water, $0.1 \mathrm{~cm}^{3}$ of a $0.1 \%$ solution of lipase, $0.8 \mathrm{~cm}^{3}$ of phosphate buffer ( $\mathrm{pH}$ of the medium corresponded to the $\mathrm{pH}$-optimum of lipase) and heat-treated for 5 minutes at $+37^{\circ} \mathrm{C}$ Then, $1.0 \mathrm{~cm}^{3}$ of a $40 \%$ suspension of hydrogenated fat with polyvinyl alcohol was added, heat-treated under the same conditions. Exactly after $1 \mathrm{~h}$ of incubation, the reaction was interrupted by the addition of $5 \mathrm{~cm}^{3}$ of $96 \%$ ethanol. In the control sample, the emulsion of hydrogenated fat was added after the addition of ethanol. In the control and experimental samples, three drops of phenolphthalein solution were added and titrated with $0.05 \mathrm{M}$ sodium hydroxide solution to a light pink color. The level of lipase activity was estimated in terms of the difference in the amount of alkali that went for the titration of the experimental and control samples with the hydrolysis of $40 \%$ emulsion of hydrogenated fat.

The activity of lipase was calculated according to the formula:

$$
\mathrm{LA}=\frac{\left(\mathrm{A}-\mathrm{A}_{1}\right)}{\mathrm{B}} * 100
$$

where $\mathrm{A}-$ is the amount of $0.05 \mathrm{M} \mathrm{NaOH}$ that went for the titration of the prototype, $\mathrm{cm}^{3}$;

$\mathrm{A}_{1}$ - is the amount of $0.05 \mathrm{M} \mathrm{NaOH}$ that went for the titration of the control sample, $\mathrm{cm}^{3}$;

$$
\mathrm{B}-\text { the amount of enzyme in the reaction mix- }
$$
ture, $\mathrm{mg}$; micromolar;

$$
100 \text { - coefficient for conversion into a }
$$

\section{LA - lipolytic activity, LU/g}

The enzyme was immobilized by physical adsorption (physical sorption) as follows: a weighed sample of the carrier $(1 \mathrm{~g})$ was impregnated with a $10 \%$ solution of the enzyme in $0.1 \mathrm{M}$ phosphate buffer, $\mathrm{pH} 7.0$ units, after which it was dried and again impregnated with the enzyme solution until the desired weight ratio of the car- rier: enzyme was reached [15].

The pH-optimum immobilized lipase was determined in such a way that buffer solution with different $\mathrm{pH}$ values of the medium in the range of $2.5 \ldots 12.0$ was added to the enzyme samples of equal activity and the enzymatic activity was determined.

The thermo-optimum of the immobilized enzyme was determined by studying for the same activity enzyme samples at a temperature of $+20 \ldots 80^{\circ} \mathrm{C}$ in the appropriate buffer, which corresponds to the $\mathrm{pH}$ optimum of this enzyme.

To determine $\mathrm{pH}$ stability, the level of activity of the enzyme sample was incubated at various $\mathrm{pH}$ values of $2.5 \ldots 12.0$ for $0 \ldots 360$ minutes, then the $\mathrm{pH}$ of the solution was adjusted to the optimal value and the enzymatic activity was determined.

The thermal stability of the immobilized lipase was studied in such a way that the activity levels of the enzyme sample in the corresponding buffer solution that corresponds to the $\mathrm{pH}$ optimum were incubated at +20 , $+37,+45$ and $+60^{\circ} \mathrm{C}$ for $0 \ldots 360 \mathrm{~min}$, then the temperature was brought to $+37^{\circ} \mathrm{C}$ and determined the activity of the enzyme.

\section{Results of the study and their discussion}

In order to obtain a stable lipase preparation that exhibits lipolytic activity sufficient for the fermentolysis of hydrogenated fat, Rhizopus japonicus lipase immobilization was carried out on carriers of inorganic origin. During the studies, the optimal conditions of sorption immobilization were selected: the media was impregnated with $10 \%$ enzyme solution in $0.1 \mathrm{M}$ phosphate buffer solution, pH 7.0 units. pH using GM 3 for agar-agar and carrageenan, GM 1 - clay (Kieselguhr (diatomaceous earth), ascanite, bergmeal) and GM 1.5 - for activated carbon and chitosan, at $+23{ }^{\circ} \mathrm{C}$ and dried the drug at $+40{ }^{\circ} \mathrm{C}$. The choice of carrier for immobilization of the lipase was carried out with the maximum preservation of initial lipolytic activity.

The experimental results of determining the optimal weight ratio of carriers: the enzyme are given in Fig. 1.

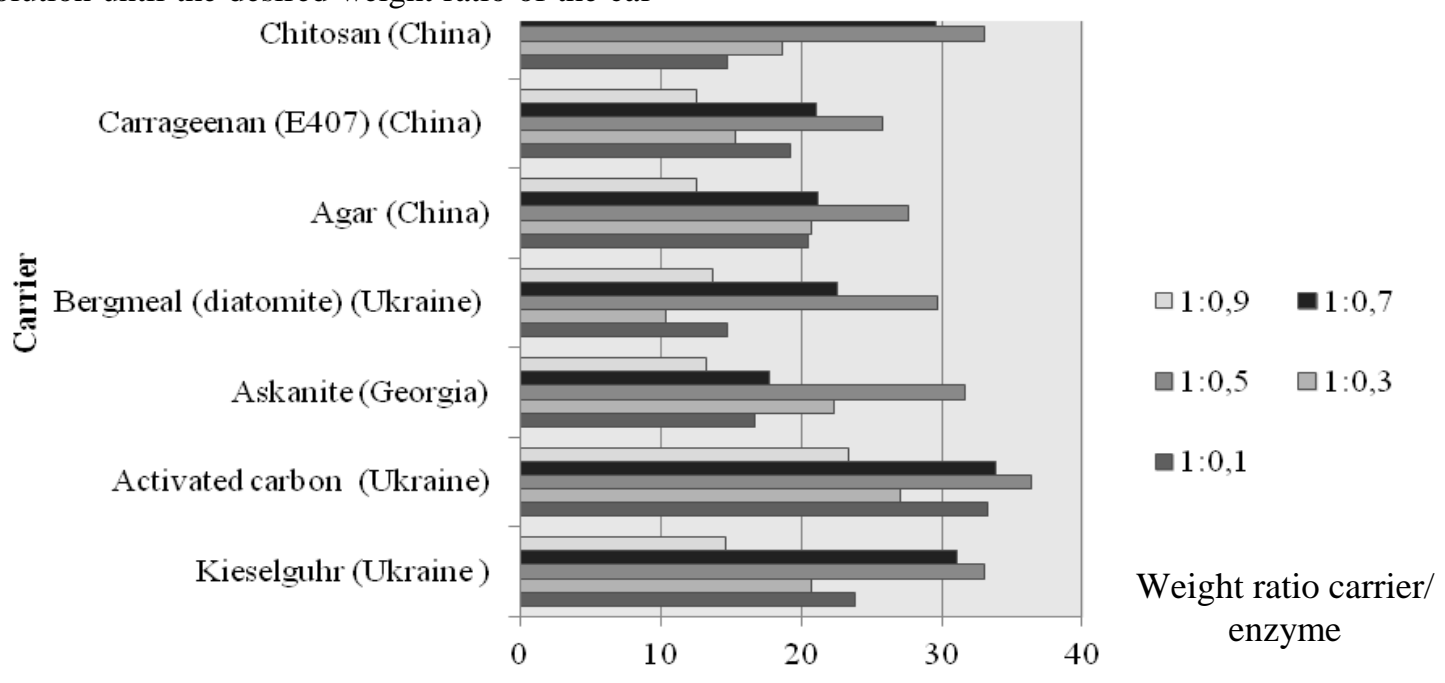

Lipolytic activity, $\%$ of the preserv. of the original.

Fig. 1 - Determination of optimal weight ratios carrier: enzyme 




Fig. 2 - Dependence of lipolytic activity immobilized particle size lipase

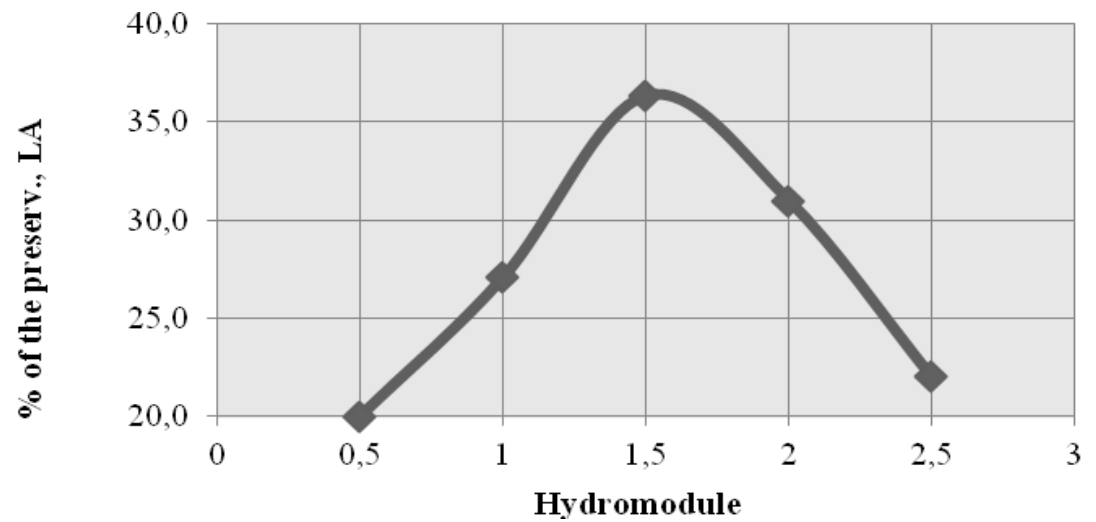

Fig. 3 - Dependence of immobilized lipase activity on the hydro-module

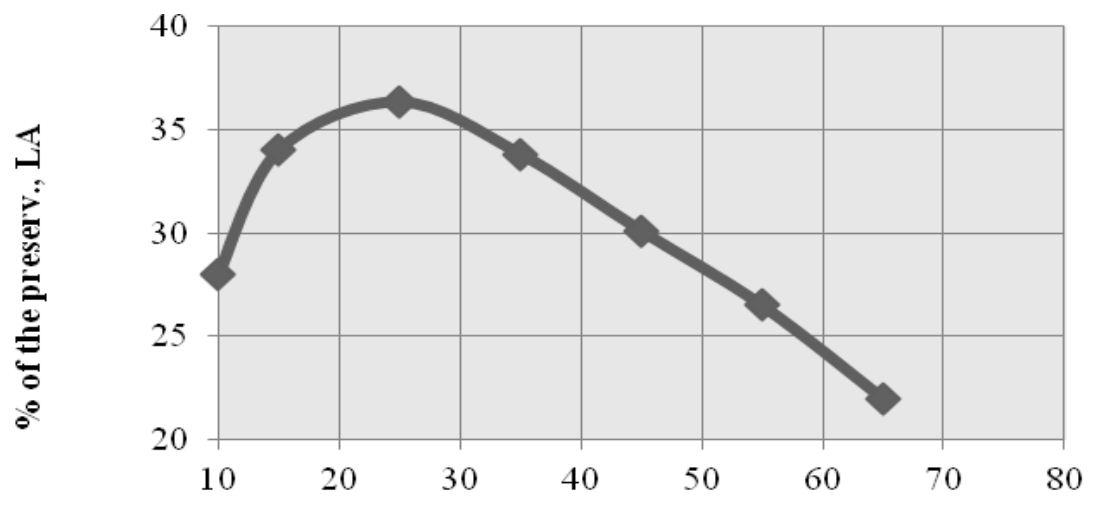

Temperature,${ }^{\circ} \mathrm{C}$

Fig. 4 - Temperature dependence of immobilized lipase activity



Fig. 5 - Dependence of the activity of immobilized lipase on the duration of immobilization
Thus, the use of activated carbon with a grain size of $2.0-2.8$ as a carrier for immobilizing of lipase, leads to maximum preservation of the original lipolytic activity. The weight ratio of carrier: enzyme, optimal in terms of preservation of lipolytic activity, was $1 \mathrm{~g}$ of biopolymer carrier per $500 \mathrm{mg}$ of lipase (1: 0.5$)$ with preservation of $36.33 \%$ of the initial activity of the native enzyme.

The following factors influence the immobilization efficiency: temperature, hydromodule (HM, solid phase-liquid weight ratio), duration of immobilization process.

Due to the fact that the physical and mechanical characteristics of the carrier significantly affect the immobilization, investigated the dependence of lipolytic activity of the immobilized form of lipase on the particle size of the matrix. The results of the studies are given in Fig. 2.

The results of the experimental data given in table. 2, allow to state that the maximum inhibitory activity is observed when using activated carbon with a particle size of 2.0-2.8.

Experimental data of the influence of the hydro-module, temperature and duration of the immobilization process on the enzymatic activity of immobilized on activated carbon at a mass ratio of carrier inhibitor $(1: 0,5)$ are shown in Fig. 3-6.

According to the results of the study of the influence of the immobilization hydro-module on the conservation of enzymatic activity, which are shown in Fig. 3 , the greatest value of the preservation of lipolytic activity is observed in HM 1.5.

The results of the study of the effect of temperature on the efficiency of the process of immobilization of lipase on activated carbon, which are shown in Fig. 4, show that the immobilized lipase is stable in the range of $+15 \ldots$ $35{ }^{\circ} \mathrm{C}$, and the highest activity is observed at $+25^{\circ} \mathrm{C}$. As the temperature rises, activity sharply decreases.

From the results of the experimental studies shown in Fig. 
5 , it is seen that the maximum preservation of lipolytic activity is observed after $15 \mathrm{~min}$ of the immobilization process.

From the results of experimental studies we can conclude that the rational conditions of immobilization of Rhizopus japonicus lipase are: GM 1.5, temperature $+25^{\circ} \mathrm{C}$, duration of immobilization 15 min. The weight ratio of the enzyme carrier is $1: 0.5$.

In order to optimize the conditions of fermentalisation of hydrogenated fat by immobilized lipase, a study of its physical and chemical properties was carried out.

The nature of the carrier surface, depending on the content of the groups of acidic or basic ionizing character, may affect the $\mathrm{pH}$-value of the immobilized enzyme. In this regard, to one degree or another, a pronounced shift in the $\mathrm{pH}$ optimum value of the immobilized enzyme to the acidic or alkaline $\mathrm{pH}$ area is possible, as well as expansion of the observed $\mathrm{pH}$ optimum area of the immobilized enzyme. $\mathrm{pH}$ optimum and $\mathrm{pH}$ stability of immobilized lipase was studied under conditions similar to that for the native enzyme (Fig. 6, 7)

The $\mathrm{pH}$ optimum of the native enzyme was about 7 units. $\mathrm{pH}$. As a result of immobilization, its $\mathrm{pH}$ optimum expands and is in the $\mathrm{pH}$ range from 6.5 to 8 (Fig. 6).

There was a significant increase in $\mathrm{pH}$ stability during prolonged incubation of the immobilized preparation with alkaline and acidic $\mathrm{pH}$. This allows us to predict its effective functioning under real digestive conditions (Fig. 2), which may be due to the stabilization of the native conformation of the protein globule under the action of sorption forces, as well as the partial suppression of autolysis processes. In acidic medium ( $\mathrm{pH} 2.5$ ), the activity of the immobilized enzyme is maintained from 50 to almost $90 \%$ for 25 minutes. In an alkaline medium ( $\mathrm{pH} 9$ ), the activity of the immobilized enzyme in the complex is significantly reduced after $150 \mathrm{~min}$. incubating it under these conditions.

Immobilization of enzymes usually leads to an increase in their thermooptimum and thermos-stability due to varying degrees of strong fixation of the native conformation of the protein molecule and, accordingly, the difficulty of denaturing it with increasing temperature.

The thermo-optimum and thermosstability of the immobilized preparation was investigated under conditions similar to the native enzyme (Fig. 8, 9).

As can be seen from the above data, immobilization of the lipase leads to



Fig. 6 - The pH optimum of Rhizopus japonicus immobilized lipase



Fig. 7 - pH stability of the lipase Rhizopus japonicus $\left(\right.$ at $\left.40^{\circ} \mathrm{C}\right)$

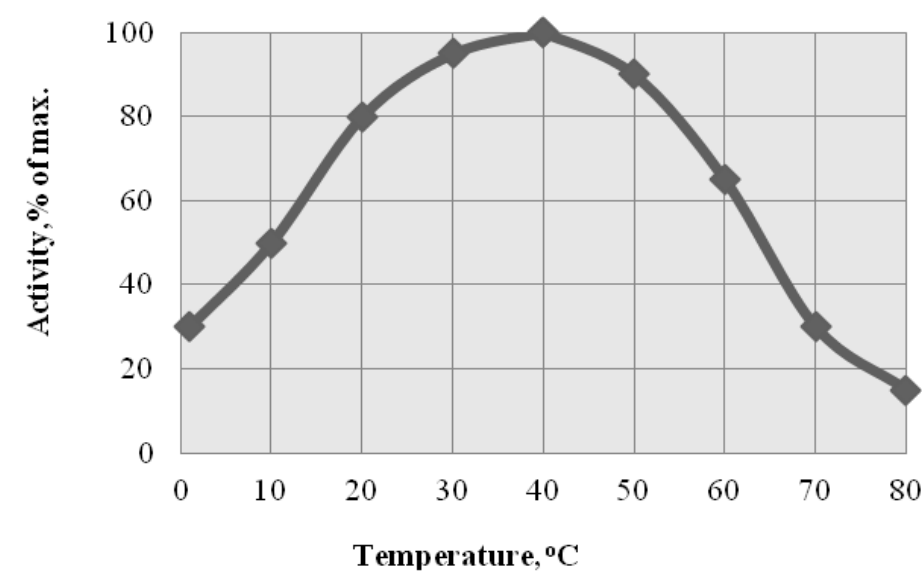

Fig. 8 - Thermo-optimum of immobilized lipase Rhizopus japonicus

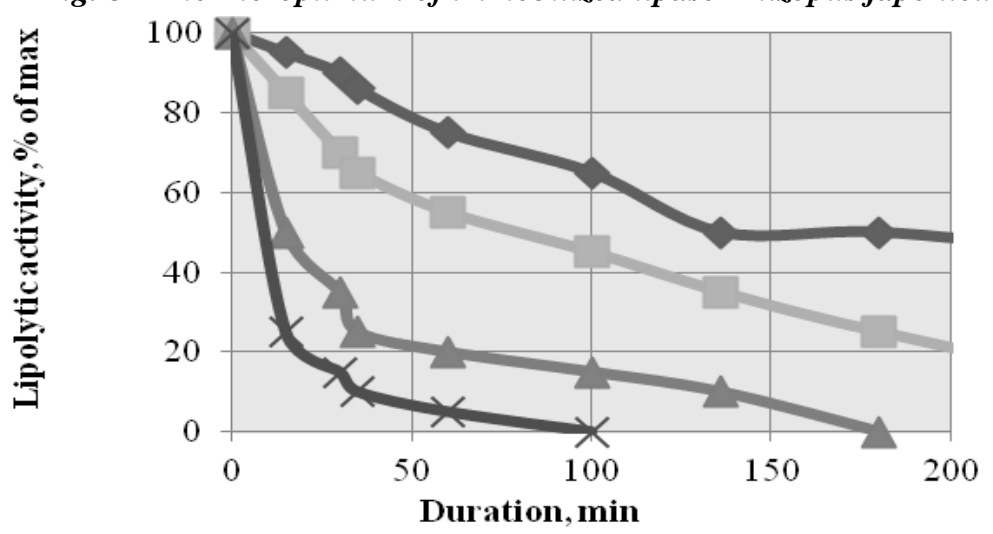

$-40^{\circ} \mathrm{C}=60^{\circ} \mathrm{C} \longrightarrow 80^{\circ} \mathrm{C} \longrightarrow 100^{\circ} \mathrm{C}$

Fig. 9 - Thermostability of Rhizopus japonicus lipase (pH 6.5) 
expansion of the thermo-optimum compared to the native enzyme (Fig. 8).

Immobilization of the lipase leads to stabilization of the enzyme during prolonged incubation at physiological temperature $\left(+40^{\circ} \mathrm{C}\right)$ and at higher temperatures (Fig. 9), which are possible when drying the final product containing the lipase.

Under these conditions, it is established that $80 \%$ of the activity of the immobilized enzyme is preserved for $50 \mathrm{~min}$, and then its value gradually decreases and after $50 \mathrm{~min}$ is $50 \%$. The activity of the immobilized enzyme for $175 \mathrm{~min}$ is completely lost at $+80^{\circ} \mathrm{C}$. Total loss of activity at $+100^{\circ} \mathrm{C}$ is $100 \mathrm{~min}$.

\section{Conclusion}

Lipase immobilization improves the conditions of processing waste hydrogenation of vegetable oils by fermentalisation. From the above results it can be seen that the use of activated carbon leads to maximum preservation of the initial lipolytic activity.

The rational conditions for Rhizopus japonicus immobilization are: HM 1.5 , temperature $+25^{\circ} \mathrm{C}$, duration of immobilization $15 \mathrm{~min}$, particle size of the matrix
2.0-2.8 mm. Lipolytic activity of the enzyme immobilized under these conditions remains more than $30 \%$ compared to native, which is a high indicator of activity retention.

It has been shown that immobilization promotes the expansion of the $\mathrm{pH}$ - and thermo-optimum of the lipase. It was determined that for the Rhizopus japonicus immobilized lipase, the $\mathrm{pH}$ optimum increased with a shift from 7.0 to 6.5 , and there was an increase in $\mathrm{pH}$ stability during prolonged incubation of the immobilized enzyme for alkaline and acidic $\mathrm{pH}$ values. It has been established that lipase immobilization leads to expansion of the thermo-optimum, as well as stabilization of the enzyme during prolonged incubation at $+40{ }^{\circ} \mathrm{C}$ and at higher temperatures $\left(+60-80{ }^{\circ} \mathrm{C}\right)$, which are possible when drying the final product.

The experimental results obtained indicate a higher stability of Rhizopus japonicus immobilized lipase compared to the native one. The high activity and stability of the immobilized lipase make it possible to recommend it for biotechnological processing of oil and fat waste. Further use of hydrolyzed waste will allow to obtain new products.

\section{REFERENCES}

1. Skliar, V., Krusir, H., Kovalenko, I., Kuznietsova, I., Shpyrko T. Rozrobka enerhoefektyvnoi tekhnolohii utylizatsii vidkhodiv oliino-zhyrovoi haluzi. Naukovi pratsi. 2019. Vol. 83(1):92-97. https://doi.org/10.15673/swonaft.v83i1.1424

2. Keleti T. Osnovyi fermentativnoy kinetiki. Moskva: Mir; 1990.

3. Paiva, A. L., Balcão, V. M., Malcata, F. X. Kinetics and mechanisms of reactions catalyzed by immobilized lipases. Enz. Microb. Technol. 2000; Vol.27: 187-204.

4. Krusir H.V. Prohnozuvannia efektyvnykh metodiv stabilizatsii roslynnykh biokorektoriv. Zernovi produkty $i$ kombykormy. 2010; N2 (38):15-18.

5. Cherno N.K., Krusyr H.V. Rusieva Ya.P. Kompleksoutvorennia yak metod immobilizatsii soievykh inhibitoriv. Kharchova nauka i tekhnolohiia. 2010; Vypusk 1: 24-27.

6. Cherno N.K., Krusir H.V., Kovalenko O.V. Biokorektory protsesiv travlennia: monohrafiia. Odesa; 2009.

7. V. Gunasekaran and D. Das, Lipase fermentation: Progress and prospects, Indian J. Biotechnol. 2005; Vol. 4: 437-445

8. Ramani K., Karthikeyan S., Boopathy R., Kennedy L.J., Mandal A.B., Sekaran G. Surface functionalized mesoporous activated carbon for the immobilization of acidic lipase and their application to hydrolysis of waste cooked oil: isotherm and kinetic studies. Process Biochem. 2012; Vol. 47: 435-445.

9. Kandasamy R., Kennedy L.J., Vidya C., Boopathy R., Sekaran J. Immobilization of acidic lipase derived from Pseudomonas gessardii onto mesoporous activated carbon for the hydrolysis of olive oil. J. Mol. Catal. B: Enzymatic. 2010; Vol. 62: 59-66.

10. Hrydziuszko Z., Dmytryk A., Majewska P., Szymacska K., Liesiene J., Jarzkbski A., Bryjak J. Screening of lipase carriers for reactions in water, biphasic and pure organic solvent systems. Acta Biochim. Polonica. 2014; Vol. 61: 1-6.

11. Thakur S. Lipases, its sources, properties and applications: A Review. Int J Sci Eng Res. 2012; Vol. 3(7): 1-29.

12. Kumar DS, Ray S. Fungal lipase Production by solid state fermentation-An overview. J Anal Bioanal Tech. 2014; Vol. 6(1): 1-10.

13. Singh AK, Mukhopadhyay M. Overview of Fungal Lipase: A Review. Appl Biochem Biotechnol. 2012; Vol. 166(2): 486-520.

14. Polyigalina G.V., Cherednichenko V.S., Rimarev L.V. Opredelenie aktivnosti fermentov: Spravochnik. Moskva: DeLi print; 2003.

15. Keyts M. Tehnika lipidologii. Vyidelenie, analiz i identifikatsiya lipidov, Moskva: Mir; 1975. 
${ }^{1}$ В. Ю. Скляр, аспірант кафедри ЕтаПТ, E-mail vsklyar1993@gmail.com

${ }^{1}$ Г.В. Крусір, д-р техн. наук професор кафедри ЕтаПТ, E-mail: krussir.65@ gmail.com

${ }^{3}$ В.Г. Захарчук, канд. техн. наук, доцент кафедри ЕТтаП,

Одеська національна академія харчових технологій, вул. Канатна, 112, м. Одеса, Украӥна, 65039

Одеський національний економічний університет, вул. Преображенська, 8, м. Одеса, Україна, 65000

\title{
ДОСЛІДЖЕННЯ ФЕРМЕНТАТИВНОГО ГІДРОЛІЗУ ВІДХОДІВ ПЕРЕРОБКИ НАСІННЯ СОНЯШНИКУ
}

\begin{abstract}
Анотація
Украӥна має розвинутий сектор сільського господарства, зокрема рослинництва, який є джерелом великого обсягу виробничих залишків та відходів. Одним з перспективних напрямків вирішення екологічних проблем виробництва зернових продуктів є переробка виробничих відходів ферментами та застосування продуктів переробки в інших галузях промисловоcmi.

Сучасні потреби стійкої екологічної практики збільшили використання ферментативних технологій у виробничих процесах. Ліпази застосовують при переробиі відходів підприємств нафти і жиру, а саме відходів зі стадії деметалізаціі гідрогенізованого жиру з рослинних олій методом ферментативного гідролізу. Робота присвячена дослідженню умов іммобілізаиї ферменту ліпази Rhizopus јаропісиs та ї̈ фізико-хімічним характеристикам. Висвітлюються фактори одержання іммобілізованих біокаталізаторів, методи та умови визначення активності та стабільності іммобілізованих ферментів. Ліполітична активність ферменту, іммобілізованого в ичи умовах, залишається більше $30 \%$ порівняно з нативним, що є високим показником збереження активності.

Було показано, щзо іммобілізація сприяс розширенню рН- та термооптимуму ліпази. Було визначено, щзо для іммобілізованої ліпази Rhizopиs јаропісиs оптимум рН збільшується зі зміщенням від 7,0 до 6,5, і спостерігається підвищення стабільності рН під час тривалої інкубації іммобілізованого ферменту для лужно-кислих значень рН. Встановлено, щьо іммобілізація ліпази призводить до розщирення термооптимуму, а також до стабілізації ферменту при тривалій інкубації при $40{ }^{\circ} \mathrm{C}$ та при більш високій температурі $\left(+60-80^{\circ} \mathrm{C}\right)$, які можливі при сушиі кінцевого продукту . Висока активність $i$ стабільність іммобілізованої ліпази дають змогу рекомендувати ї̈ для біотехнологічної переробки олійно-жирових відхо-
\end{abstract} dis.

Ключові слова: екологічна біотехнологія, відходи, саломас, олійно-жирова галузь, іммобілізачія, фермент, ліпаза, Rhizopus japonicus, адсорбиія.

\section{REFERENCES}

1. Скляр, В., Крусір, Г., Коваленко, І., Кузнєцова, І., Шпирко Т. Розробка енергоефективної технології утилізації відходів олійно-жирової галузі // Наукові праиі - Одеса, Одеська національна академія харчових технологій: 2019. Том 83, випуск 1. - C. 92-97. https://doi.org/10.15673/swonaft.v83i1.1424

2. Keleti T. Osnovyi fermentativnoy kinetiki. Moskva, 1990. Mir. 350 s.

3. Paiva, A. L., Balcão, V. M., Malcata, F. X. Kinetics and mechanisms of reactions catalyzed by immobilized lipases // Enz. Microb. Technol. 2000. Vol.27. P. 187-204.

4. Krusir H.V. Prohnozuvannia efektyvnykh metodiv stabilizatsii roslynnykh biokorektoriv // Zernovi produkty i kombykormy. 2010. N2 (38). S.15-18.

5. Cherno N.K., Krusir H.V. Rusieva Ya.P. Kompleksoutvorennia yak metod immobilizatsii soievykh inhibitoriv // Kharchova nauka i tekhnolohiia. 2010. Vypusk 1. - S.24-27.

6. Cherno N.K., Krusir H.V., Kovalenko O.V. Biokorektory protsesiv travlennia: monohrafiia. Odesa, 2009. $256 \mathrm{~s}$.

7. V. Gunasekaran and D. Das, Lipase fermentation: Progress and prospects, Indian J. Biotechnol. 2005. Vol. 4. P. 437-445

8. Ramani K., Karthikeyan S., Boopathy R., Kennedy L.J., Mandal A.B., Sekaran G. Surface functionalized mesoporous activated carbon for the immobilization of acidic lipase and their application to hydrolysis of waste cooked oil: isotherm and kinetic studies // Process Biochem. 2012. Vol. 47. P. 435-445.

9. Kandasamy R., Kennedy L.J., Vidya C., Boopathy R., Sekaran J. Immobilization of acidic lipase derived from Pseudomonas gessardii onto mesoporous activated carbon for the hydrolysis of olive oil // J. Mol. Catal. B: Enzymatic. 2010. Vol. 62. P. 59-66.

10. Hrydziuszko Z., Dmytryk A., Majewska P., Szymacska K., Liesiene J., Jarzkbski A., Bryjak J. Screening of lipase carriers for reactions in water, biphasic and pure organic solvent systems // Acta Biochim. Polonica. 2014. Vol. 61. P. 1-6.

11. Thakur S. Lipases, its sources, properties and applications: A Review // Int J Sci Eng Res. 2012. Vol. 3, No. 7. P. 1-29.

12. Kumar DS, Ray S. Fungal lipase Production by solid state fermentation-An overview // J Anal Bioanal Tech. 2014. Vol. 6 , No. 1. P. 1-10.

13. Singh AK, Mukhopadhyay M. Overview of Fungal Lipase: A Review // Appl Biochem Biotechnol. 2012. Vol. 166. No. 2. P. 486-520.

14. Polyigalina G.V., Cherednichenko V.S., Rimarev L.V. Opredelenie aktivnosti fermentov: Spravochnik. Moskva: DeLi print, 2003. $375 \mathrm{~s}$.

Keyts M. Tehnika lipidologii. Vyidelenie, analiz i identifikatsiya lipidov, Moskva: Mir, 1975. 324 s.

\section{Received 04.10.2019}

Revised 22.12.2019

Reviewed 06.11.2019

Approved 03.03.2020

Cite as Vancouver Citation Style

Skliar V., Krusir G., Zakharchuk V. Investigation of enzymatic hydrolysis of fatty waste processing of sunflower seeds by immobi-

lized lipase. Grain Products and Mixed Fodder's, 2020; 20 (1, 77): 5-11. DOI:

Cite as State Standard of Ukraine 8302:2015

Investigation of enzymatic hydrolysis of fatty waste processing of sunflower seeds by immobilized lipase / Skliar V. et al. // Grain Products and Mixed Fodder's. 2020. Vol. 20, Issue 1 (77). P. 5-11. DOI:

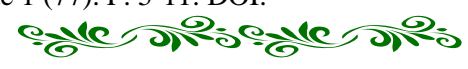

